\title{
Changes in Intracellular Calcium and Glutathione in Astrocytes as the Primary Mechanism of Amyloid Neurotoxicity
}

\author{
Andrey Y. Abramov, ${ }^{1}$ Laura Canevari, ${ }^{2}$ and Michael R. Duchen ${ }^{1}$ \\ ${ }^{1}$ Mitochondrial Biology Group, Department of Physiology, University College London, London WC1E 6BT, United Kingdom, and ${ }^{2}$ Miriam Marks Division \\ of Neurochemistry, Institute of Neurology, London WC1N 3BG, United Kingdom
}

\begin{abstract}
Although the accumulation of the neurotoxic peptide $\beta$ amyloid $(\beta A)$ in the CNS is a hallmark of Alzheimer's disease, the mechanism of $\beta \mathrm{A}$ neurotoxicity remains controversial. In cultures of mixed neurons and astrocytes, we found that both the full-length peptide $\beta \mathrm{A}$ $(1-42)$ and the neurotoxic fragment $(25-35)$ caused sporadic cytoplasmic calcium [intracellular calcium $\left.\left(\left[\mathrm{Ca}^{2+}\right]_{\mathrm{c}}\right)\right]$ signals in astrocytes that continued for hours, whereas adjacent neurons were completely unaffected. Nevertheless, after $24 \mathrm{hr}$, although astrocyte cell death was marginally increased, $\sim 50 \%$ of the neurons had died. The $\left[\mathrm{Ca}^{2+}\right]_{c}$ signal was entirely dependent on $\mathrm{Ca}^{2+}$ influx and was blocked by zinc and by clioquinol, a heavy-metal chelator that is neuroprotective in models of Alzheimer's disease. Neuronal death was associated with $\mathrm{Ca}^{2+}$-dependent glutathione depletion in both astrocytes and neurons. Thus, astrocytes appear to be the primary target of $\beta \mathrm{A}$, whereas the neurotoxicity reflects the neuronal dependence on astrocytes for antioxidant support.
\end{abstract}

Key words: $\beta$-amyloid; intracellular calcium; astrocyte; neuron; Alzheimer; glutathione

\section{Introduction}

Alzheimer's disease $(\mathrm{AD})$ is a neurodegenerative disorder characterized by a progressive cognitive decline resulting from selective neuronal dysfunction, synaptic loss, and neuronal cell death. It is accompanied by the deposition of the $\beta$-amyloid peptide $(\beta A)$, a polypeptide of $39-43$ aa that is thought to play a major role in the pathogenesis of the disorder (Small and McLean, 1999). Aggregated $\beta A$ is neurotoxic. Although $\beta A$ neurotoxicity has been associated with oxidative stress and the reduction of endogenous antioxidants (Behl et al., 1994; Casley et al., 2002a), with mitochondrial damage (Casley et al., 2002b) and with the destabilization of intracellular calcium $\left(\left[\mathrm{Ca}^{2+}\right]_{c}\right)$ homeostasis, both in neurons (Mattson et al., 1992) and in glial cells (Stix and Reiser,1998), the mechanism of $\beta$ A-induced neurotoxicity remains uncertain.

Amyloid $\beta$ peptides have been shown recently to form pores in artificial membranes; it has been suggested that they may also act as pore formers in intact neuronal membranes, in which they appear to form $\mathrm{Ca}^{2+}$-permeable channels (Arispe et al., 1993; Lin et al., 2001). $\beta$ A has also been shown to have effects on a variety of types of ion-selective channels, including voltage-gated $\mathrm{Ca}^{2+}$ permeant channels (Blanchard et al., 1997; Ueda et al., 1997; Rovira et al., 2002). More subtle changes in $\left[\mathrm{Ca}^{2+}\right]_{\mathrm{c}}$ signaling have also been demonstrated after long-term exposure to $\beta \mathrm{A}$ (Mattson and Chan, 2001), suggesting a disturbance of $\left[\mathrm{Ca}^{2+}\right]_{c}$

Received Feb. 12, 2003; revised April 4, 2003; accepted April 10, 2003

This work was supported by the Wellcome Trust, the Royal Society, and the Miriam Marks Foundation. We thank Drs. Frances Edwards and Anna de Simoni for providing hippocampal explant cultures and Profs. S. Bolsover and J. B. Clark and Drs. R. Dumollard and J. Jacobson for their invaluable discussion and suggestions.

Correspondence should be addressed to Michael R. Duchen, Department of Physiology, University College London, Gower Street, London WC1E 6BT, UK. E-mail: m.duchen@ucl.ac.uk.

Copyright $\odot 2003$ Society for Neuroscience $\quad$ 0270-6474/03/235088-08\$15.00/0 homeostatic mechanisms that may reflect changes in cellular metabolism.

Reports on the effects of $\beta \mathrm{A}$ on $\left[\mathrm{Ca}^{2+}\right]_{\mathrm{c}}$ in astrocytes are controversial. With exposure to $\beta \mathrm{A}$, some authors have found that astrocyte $\left[\mathrm{Ca}^{2+}\right]_{\mathrm{c}}$ increases (Stix and Reiser, 1998), whereas in the hands of others, astrocyte $\left[\mathrm{Ca}^{2+}\right]_{c}$ decreases (Meske et al., 1998). The effect of $\beta \mathrm{A}$ on $\left[\mathrm{Ca}^{2+}\right]_{\mathrm{c}}$ homeostasis in astrocytes is potentially very important, considering the interplay between neuronal and glial signals revealed recently (Haydon, 2001) and the proposed glia-related pathomechanisms in AD (Harkany et al., 2000; Schubert et al., 2001). Glial cells play a major supportive role toward neurons, which includes supplying metabolic substrates and the precursors of the antioxidant glutathione (GSH) (Dringen, 2000) and removing excitatory amino acids such as glutamate from the extracellular space (Takahashi et al., 1997), processes that play a critical role in neuroprotection. These roles may be undermined by the $\beta \mathrm{A}$-induced generation of reactive oxygen species (ROS) and the inhibition of glutamate uptake (Markesbery,1997; Harkany et al.,2000), resulting in neuronal damage as a consequence of impaired astrocytic support function.

\section{Materials and Methods}

Cell culture. Mixed cultures of hippocampal neurons and glial cells were prepared as described previously (Vergun et al., 2001), with modifications, from Sprague Dawley rat pups $2-4 \mathrm{~d}$ postpartum [University College London (UCL) breeding colony]. Hippocampi were removed into ice-cold Gey's salt solution (Invitrogen, Paisley, UK) with $20 \mu \mathrm{g} / \mathrm{ml}$ of gentamicin. The tissue was minced and trypsinized $(0.1 \%$ for $15 \mathrm{~min}$ at $37^{\circ} \mathrm{C}$ ), triturated, and plated on poly-D-lysine-coated coverslips and cultured in Neurobasal medium (Invitrogen) supplemented with $\mathrm{B}_{27}$ (Invitrogen) and $2 \mathrm{~mm}$ L-glutamine. Cultures were maintained at $37^{\circ} \mathrm{C}$ in a humidified atmosphere of 5\% $\mathrm{CO}_{2}$ and $95 \%$ air, fed twice a week, and maintained for a minimum of $10 \mathrm{~d}$ before experimental use to ensure the expression of glutamate and other receptors. Neurons were easily distinguishable from glia: they appeared phase-bright, had smooth, rounded so- 
mata and distinct processes, and lay just above the focal plane of the glial layer. Cells were used at 10-20 d in vitro (DIV) unless stated otherwise.

Isolated cortical astrocytes were prepared as described previously (Boitier et al., 1999). Cerebra taken from adult Sprague Dawley rats (UCL breeding colony) were chopped and triturated until homogeneous, passed through a $297 \mu \mathrm{m}$ mesh, and trypsinized $(50,000 \mathrm{U} / \mathrm{ml}$ of porcine pancreas; Sigma, Gillingham, UK) with $336 \mathrm{U} / \mathrm{ml}$ of DNase 1 (bovine pancreas, Sigma), and $1.033 \mathrm{U} / \mathrm{ml}$ of collagenase (Sigma) at $37^{\circ} \mathrm{C}$ for 15 min. After the addition of fetal bovine serum ( $10 \%$ of final volume) and filtering through $140 \mu \mathrm{m}$ mesh, the tissue was centrifuged through $0.4 \mathrm{M}$ sucrose (400 gm, $10 \mathrm{~min}$ ), and the resulting pellet was transferred to Minimal Essential Medium supplemented with $5 \%$ fetal bovine serum, 2 $\mathrm{mm}$ glutamine, and $1 \mathrm{~mm}$ malate in tissue culture flasks precoated with $0.01 \%$ poly-D-lysine. The cells reached confluence at 12-14 DIV; they were harvested and reseeded onto $24 \mathrm{~mm}$ diameter glass coverslips (BDH Chemicals, Poole, UK) precoated with $0.01 \%$ poly-D-lysine for fluorescence measurements, and used over $2-4 \mathrm{~d}$.

Peptides and treatments. $\beta \mathrm{A} 25-35, \beta \mathrm{A} 1-42$, and $\beta \mathrm{A} 35-25$ (Bachem, St. Helens, UK) were dissolved at $1 \mathrm{~mm}$ in sterile ultrapure water (Milli-Q standard; Millipore, Watford, UK) and kept frozen until use. The peptides were added under the microscope, except for GSH and neurotoxicity measurements, where they were added $24 \mathrm{hr}$ before the experiment. $\beta$ A25-35 was used at concentrations of up to $50 \mu \mathrm{m}$ to ensure that it was present in molar excess compared with inhibitors and so to exclude any direct interaction.

Microscopy. Fluorescence measurements were obtained using a Nikon (Tokyo, Japan) epifluorescence inverted microscope with a $20 \times$ fluorite objective. Excitation light from a Xenon arc lamp is selected using $10 \mathrm{~nm}$ bandpass filters centered at 340,360, and $380 \mathrm{~nm}$ housed in a computercontrolled filter wheel (Cairn Research, Faversham, UK). Emitted light passed through a long-pass filter to a cooled CCD camera (Orca ER; Hamamatsu, Welwyn Garden City, UK). All imaging data were collected at intervals of 10-15 sec, digitized, and analyzed using Kinetic Imaging (Wirral, UK) software. Cells were protected from phototoxicity by interposing a shutter in the light path to limit exposure between the acquisition of successive images.

Confocal images were obtained using a Zeiss (Oberkochen, Germany) 510 confocal laser scanning microscope and a $40 \times$ oil immersion objective. The $488 \mathrm{~nm}$ argon laser line was used to excite fluo-4 fluorescence, which was measured using a bandpass filter from 505 to $550 \mathrm{~nm}$. Illumination intensity was kept to a minimum (at $0.1 \%$ of laser output) to avoid phototoxicity, and the pinhole was set to give an optical slice of $\sim 2 \mu \mathrm{m}$.

$\left[\mathrm{Ca}^{2+}\right]_{c}$ measurements. Cells were loaded for $30 \mathrm{~min}$ at room temperature with $5 \mu \mathrm{M}$ fura-2 AM (Molecular Probes, Eugene, OR) and 0.005\% Pluronic in a HEPES-buffered salt solution composed of (in mM): 156 $\mathrm{NaCl}, 3 \mathrm{KCl}, 2 \mathrm{MgSO}_{4}, 1.25 \mathrm{KH}_{2} \mathrm{PO}_{4}, 2 \mathrm{CaCl}_{2}, 10$ glucose, and $10 \mathrm{HEPES}$, $\mathrm{pH}$ 7.35. Traces, obtained using the cooled CCD imaging system, are presented as ratios of excitation at 340 and $380 \mathrm{~nm}$, both with emission at $>515 \mathrm{~nm}$. For some measurements, $\left[\mathrm{Ca}^{2+}\right]_{\mathrm{i}}$ was calculated using the equation (Grynkiewicz et al., 1985): $\left[\mathrm{Ca}^{2+}\right]_{\mathrm{c}}=K\left(R-R_{\min }\right) /\left(R_{\max }-R\right)$, where $R$ is the fluorescence ratio $(340 / 380 \mathrm{~nm})$ and $K$ is the effective dissociation constant of fura-2. $R_{\max }$ and $R_{\min }$ were determined by the application of $50 \mu \mathrm{M}$ digitonin followed by $1 \mathrm{~mm} \mathrm{MnCl}$.

All data presented were obtained from at least five coverslips and two to three different cell preparations.

For confocal imaging, cells were loaded with fluo-4 AM ( $5 \mu \mathrm{M}$; Molecular Probes) for $20 \mathrm{~min}$, followed by washing. Data are presented normalized with respect to the first image of the sequence.

GSH measurements. To measure GSH, cells were incubated with $50 \mu \mathrm{M}$ monochlorobimane (MCB; Molecular Probes) in HEPES-buffered salt solution at room temperature for $40 \mathrm{~min}$, or until a steady state had been reached before images were acquired for quantitation (Keelan et al., 2001). The cells were then washed with HEPES-buffered salt solution, and images of the fluorescence of the MCB-GSH adduct were acquired using the cooled CCD imaging system as described using excitation at $380 \mathrm{~nm}$ and emission at $>400 \mathrm{~nm}$.

Toxicity experiments. For toxicity assays we loaded cells simultaneously with $20 \mu \mathrm{M}$ propidium iodide (PI), which is excluded from viable cells but exhibits a red fluorescence after a loss of membrane integrity, and 4.5 $\mu \mathrm{M}$ Hoechst 33342 (Molecular Probes), which gives a blue stain to chro-
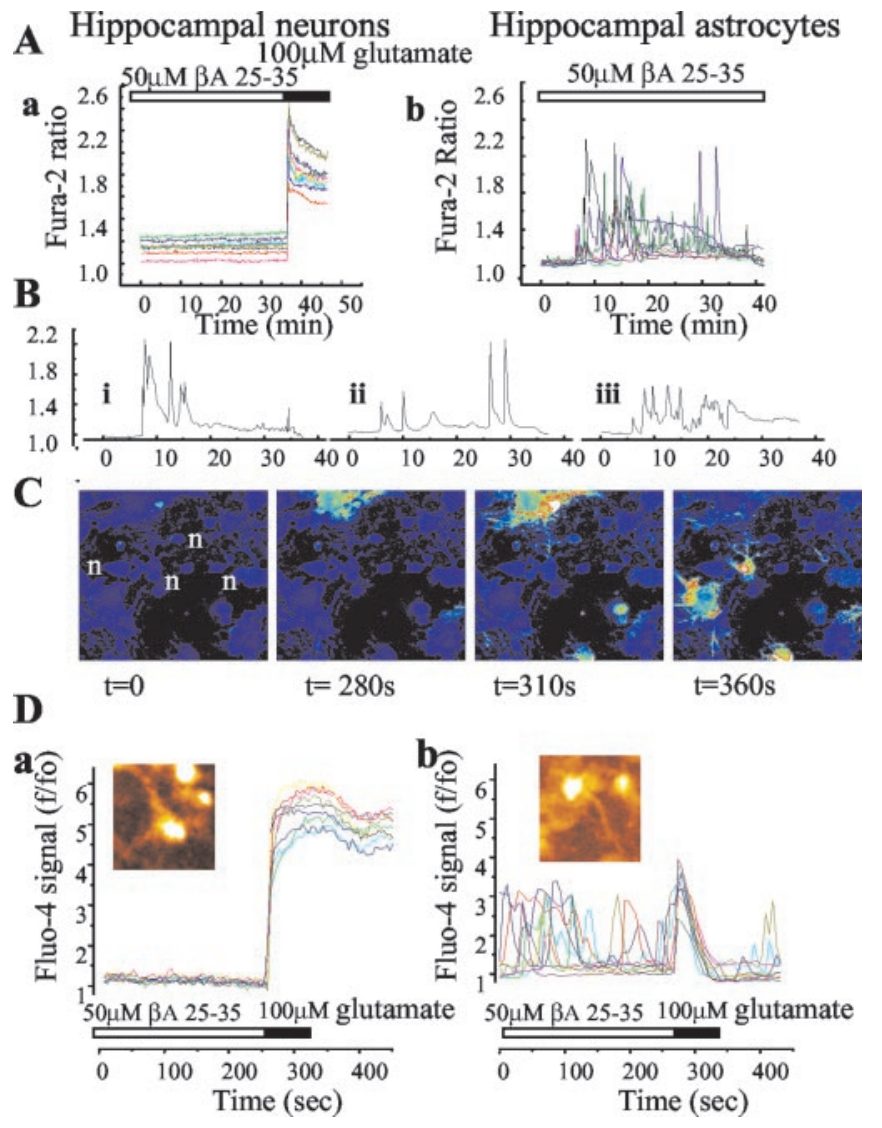

Figure 1. $\quad \beta$ Amyloid raises $\left[\mathrm{Ca}^{2+}\right]_{\mathrm{c}}$ in astrocytes and not in neurons. $A$, Records of fura-2 fluorescence from neurons $(a)$ and astrocytes $(b)$ in hippocampal cocultures after exposure to $\beta A 25-35$ peptide $(50 \mu \mathrm{M})$. The neurons showed no change in signal over a period of $35 \mathrm{~min}$. Their identity was confirmed by their response to glutamate $(100 \mu \mathrm{m})$ at the end of this period. The astrocytes $(b)$ showed complex $\left[\mathrm{Ca}^{2+}\right]_{c}$ fluctuations starting after $\sim 5-6$ min of exposure to $\beta$ A25-35 $(50 \mu \mathrm{M})$. These could continue for many hours. Some sample traces are extracted from this population and illustrated as $B i$, Bii, and Biii. The images in C are taken from a time series of confocal images of a hippocampal coculture loaded with fluo-4. The field includes four neurons ( $n$ ) surrounded by astrocytes. Once again, the astrocytes show complex transient and localized $\left[\mathrm{Ca}^{2+}\right]_{C}$ responses whereas the neurons show no change in signal at all. The traces in $D$ originate from confocal images of a fluo-4-loaded hippocampal explant culture. Once again, neurons that showed a robust response to glutamate application showed no response to $\beta \mathrm{A}(a)$ whereas astrocytes showed complex $\left[\mathrm{Ca}^{2+}\right]_{\mathrm{c}}$ fluctuations and only a small transient metabotropic $\left[\mathrm{Ca}^{2+}\right]_{c}$ response to glutamate $(b)$. An image of a responding cell is inset for each signal.

matin, to count the total number of cells. Using phase-contrast optics, a bright-field image allowed the identification of neurons, which look quite different from the flatter glial component and also lie in a different focal plane, above the glial layer. A total of 600-800 neurons or glial cells were counted in 20-25 fields of each coverslip. Each experiment was repeated five or more times using separate cultures.

Statistical analysis. Statistical analysis and exponential curve fitting were performed using Origin 7 (Microcal Software Inc., Northampton, MA) software. Results are expressed as means \pm SEM.

\section{Results}

We have used digital imaging techniques to explore the effects of $\beta \mathrm{A}$ on $\left[\mathrm{Ca}^{2+}\right]_{\mathrm{c}}$ signals, antioxidant status, and cell viability in cultures of mixed hippocampal neurons and astrocytes in cultures ranging from 10 to 45 DIV. Application of either the fulllength peptide (1-42; $100 \mathrm{~nm}$ to $10 \mu \mathrm{M})$ or the $25-35$ aa fragment $(1-50 \mu \mathrm{M})$ of $\beta \mathrm{A}$ had no effect on $\left[\mathrm{Ca}^{2+}\right]_{\mathrm{c}}$ signals in neurons, which remained quiescent over periods of up to $6 \mathrm{hr}(n=456$ cells) (Fig. 1 $A a, C$ ). After 30-40 min of incubation with $\beta$ A the cells showed robust and reversible responses to the application of 
glutamate $(100 \mu \mathrm{M})$ (Fig. $1 \mathrm{Aa})$ or to depolarization with $50 \mathrm{~mm}$ $\mathrm{KCl}$, confirming both their viability and their neuronal identity. Moreover, the presence of $\beta \mathrm{A} 25-35$ or $\beta \mathrm{A} 1-42$ did not change the amplitude of the $\left[\mathrm{Ca}^{2+}\right]_{\mathrm{c}}$ response to glutamate or to $50 \mathrm{mM}$ $\mathrm{KCl}$; the response to the latter was $726 \pm 89 \mathrm{nM}(n=59$ cells $)$ in control and $759 \pm 97 \mathrm{nM}(n=96$ cells $)$ in $\beta$ A-incubated neurons.

Remarkably, astrocytes in the same cultures showed dramatic $\left[\mathrm{Ca}^{2+}\right]_{\mathrm{c}}$ signals after exposure to $\beta \mathrm{A}$, often occurring in cells surrounding quiescent neurons (Fig. $1 \mathrm{Ab}, B, C$ ) Similar $\left[\mathrm{Ca}^{2+}\right]_{c}$ signals were seen in response to both the 25-35 peptide and the full-length 1-42 peptide, but no responses were seen to the reverse peptide $35-25(n=135$ cells $)$. All $\left[\mathrm{Ca}^{2+}\right]_{\mathrm{c}}$ signals started after a delay of $\sim 5-15 \mathrm{~min}$ and showed three patterns of response: (1) sporadic increases in $\left[\mathrm{Ca}^{2+}\right]_{\mathrm{C}}$, seen as low-amplitude $(100-200 \mathrm{~nm})\left[\mathrm{Ca}^{2+}\right]_{\mathrm{c}}$ oscillations or fluctuations; (2) larger spikes, followed by sustained elevated $\left[\mathrm{Ca}^{2+}\right]_{\mathrm{c}}(1-2 \mu \mathrm{M})$, and (3) very large increases in $\left[\mathrm{Ca}^{2+}\right]_{\mathcal{c}}$, usually followed by loss of cell viability. After washing the cells with $\beta \mathrm{A}$-free saline, the responses persisted for up to $6 \mathrm{hr}$ (data not shown).

Because responses like these have not been described previously, we were concerned that the properties of the cells might be dictated by our culture conditions. Therefore, we repeated the experiments using other culture systems. Experiments using cultures of cortical astrocytes prepared in the same way gave results identical to those from the hippocampus (data not shown). We also used hippocampal explant cultures, in which the properties of the tissue in vivo are well retained. Confocal imaging of explant cultures loaded with fluo-4 again showed that exposure to $\beta \mathrm{A} 25-35(50 \mu \mathrm{M})$ provoked a selective increase in activity in glial cells in the culture (Fig. $1 \mathrm{Db}$ ). Neurons were identified as the only cells in the culture to show a rise in $\left[\mathrm{Ca}^{2+}\right]_{\mathrm{c}}$ with $50 \mathrm{~mm} \mathrm{KCl}$ and by their larger and more sustained response to glutamate (100 $\mu \mathrm{M}$ ) (Fig. 1Da). The astrocytes showed transient and oscillatory activity with $\beta \mathrm{A}$, showed no response to $50 \mathrm{mM} \mathrm{KCl}$, and their response to glutamate was a small transient response that reflects activation of metabotropic glutamate receptors ( $n=5$ cultures). Because the responses in dissociated cultures and explants appeared similar, the dissociated cultures were used for the remainder of the experiments described.

\section{Astrocyte $\left[\mathrm{Ca}^{2+}\right]_{\mathrm{c}}$ responses to $\beta \mathrm{A}$ are dependent on extracellular $\mathrm{Ca}^{2+}$ and independent of intracellular $\mathrm{Ca}^{2+}$ stores}

The $\left[\mathrm{Ca}^{2+}\right]_{\mathrm{c}}$ responses to $\beta$ A were never observed in $\mathrm{Ca}^{2+}$-free saline ( $n=231$ cells) (Fig. $2 A$ ). However, if cells were exposed to $\beta \mathrm{A}$ in a $\mathrm{Ca}^{2+}$-free saline and were then washed with $\beta \mathrm{A}$-free, $\mathrm{Ca}^{2+}$-containing buffer, $\left[\mathrm{Ca}^{2+}\right]_{\mathrm{c}}$ responses were then seen in the astrocytes ( $n=69$ cells) (Fig. $2 B$, bottom) whereas neuronal $\left[\mathrm{Ca}^{2+}\right]_{\mathrm{c}}$ did not change beyond the small increase associated with the restoration of basal $\mathrm{Ca}^{2+}$ influx ( $n=64$ cells) (Fig. $2 B$, top). These data show that $(1)$ the changes in $\left[\mathrm{Ca}^{2+}\right]_{\mathrm{c}}$ in astrocytes are initiated through $\mathrm{Ca}^{2+}$ influx from external sources, (2) the initiation of the action of $\beta$ A does not require the presence of $\mathrm{Ca}^{2+}$, and (3) the effect persists despite removal of $\beta$ A from the saline.

The oscillatory $\left[\mathrm{Ca}^{2+}\right]_{c}$ signals appeared typical of $\mathrm{IP}_{3}$ mediated $\left[\mathrm{Ca}^{2+}\right]_{\mathrm{c}}$ release from endoplasmic reticulum (ER) seen in astrocytes in response to a range of agonists (Peuchen et al., 1996) and to mechanical stimulation (Charles et al., 1991). Therefore, we considered whether external $\mathrm{Ca}^{2+}$ acts as a trigger to activate phospholipase $\mathrm{C}$ (PLC), which would generate $\mathrm{IP}_{3}$ and so mobilize $\mathrm{ER} \mathrm{Ca}^{2+}$. However, the experiments illustrated in Figure 3 suggest that PLC- and $\mathrm{IP}_{3}$-mediated signaling do not play a significant role in the $\beta \mathrm{A}$-induced $\left[\mathrm{Ca}^{2+}\right]_{\mathrm{c}}$ signals. Thus,
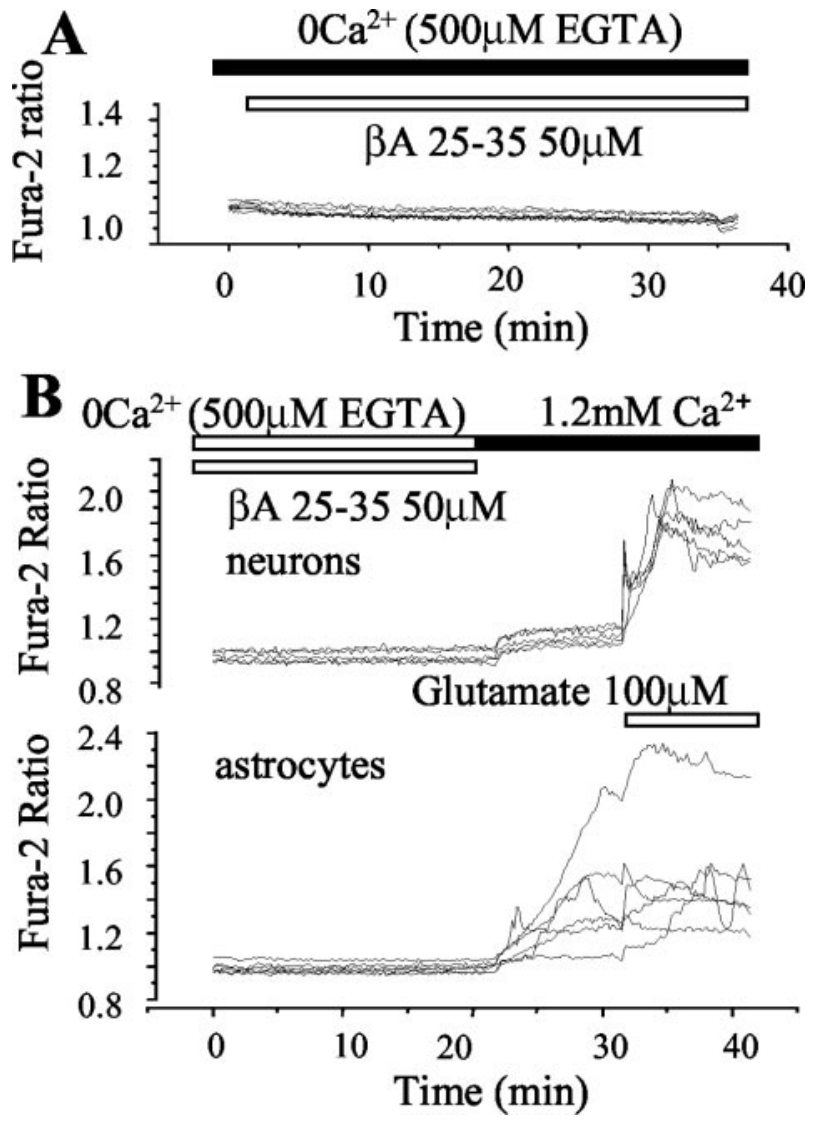

Figure 2. $\quad\left[\mathrm{Ca}^{2+}\right]_{\mathrm{c}}$ responses to $\beta \mathrm{A}$ are dependent on extracellular $\mathrm{Ca}^{2+} \cdot A$, In the absence of external $\mathrm{Ca}^{2+}$, cortical astrocytes showed no change in $\left[\mathrm{Ca}^{2+}\right]_{\mathrm{C}}$ after exposure to $\beta A 25-35$ $(50 \mu \mathrm{M}) . B$, In a coculture exposed to $\beta \mathrm{A} 25-35(50 \mu \mathrm{m})$ in the absence of external $\mathrm{Ca}^{2+}{ }^{2+}$ no response was seen in either neurons or astrocytes. $\beta A$ was then washed out and external $\mathrm{Ca}^{2+}$ added. Despite the removal of the $\beta A$, the addition of $\mathrm{Ca}^{2+}$ caused a large increase in $\left[\mathrm{Ca}^{2+}\right]_{\mathrm{c}}$ in the astrocytes but only a very small change in the neurons, reflecting the restoration of basal calcium entry. Once again, the neuronal identity was confirmed by the response to $100 \mu \mathrm{M}$ glutamate at the end of the experiment.

U73122 (5 $\mu \mathrm{M}$ ), an inhibitor of phospholipase C (Fig. 3A) did not significantly impair the $\left[\mathrm{Ca}^{2+}\right]_{\mathrm{c}}$ astrocyte responses to $\beta \mathrm{A}(n=$ 89 cells). Similarly, 2-APB, $(40 \mu \mathrm{M})$ an inhibitor of $\mathrm{IP}_{3}-$ dependent $\mathrm{Ca}^{2+}$ release, failed to reduce $\beta$ A-induced $\left[\mathrm{Ca}^{2+}\right]_{\mathrm{c}}$ signals in astrocytes ( $n=35$ cells) (Fig. $3 B$ ), whereas it completely blocked the $\left[\mathrm{Ca}^{2+}\right]_{\mathrm{c}}$ increase induced by ATP $(100 \mu \mathrm{M}$; data not shown), which acts at purinergic receptors $\left(\mathrm{P}_{2 \mathrm{U}}\right)$ to promote $\mathrm{IP}_{3^{-}}$ dependent $\mathrm{ER} \mathrm{Ca}^{2+}$ release (Peuchen et al., 1996).

Although the expression and role of ryanodine receptors (RyRs) in astrocytes is debatable (Matyash et al., 2002), we also tested the effect of the RyR inhibitor dantrolene $(10 \mu \mathrm{m})$, which again had no significant effect on the $\beta$ A-induced $\left[\mathrm{Ca}^{2+}\right]_{\mathrm{c}}$ signal $(n=46$ cells) (Fig. 3C). The incubation of astrocytes with $0.1-1$ $\mu \mathrm{M}$ thapsigargin (an inhibitor of $\mathrm{ER} \mathrm{Ca}^{2+}$ pumps) completely depleted $\mathrm{Ca}^{2+}$ from the ER, demonstrated by the absence of a $\left[\mathrm{Ca}^{2+}\right]_{\mathrm{c}}$ response to ATP $(100 \mu \mathrm{M})$ (Fig. 3D). The addition of $\beta$ A again then induced a $\left[\mathrm{Ca}^{2+}\right]_{\mathrm{c}}$ response that was not significantly different from the control responses (Fig. 3D). In this instance, values of peak $\left[\mathrm{Ca}^{2+}\right]_{\mathrm{c}}$ after thapsigargin were $390 \pm 54 \mathrm{nM}$, compared with control responses to $\beta$ A with peak values of $456 \pm$ $57 \mathrm{~nm}(n=301$ cells; $p>0.05)$. We also noted that the resting $\mathrm{Ca}^{2+}$ level, which was usually slightly elevated after exposure to thapsigargin because of the activation of store-operated $\mathrm{Ca}^{2+}$ influx, was slightly depressed by $\beta \mathrm{A}$, suggesting that, if anything, 

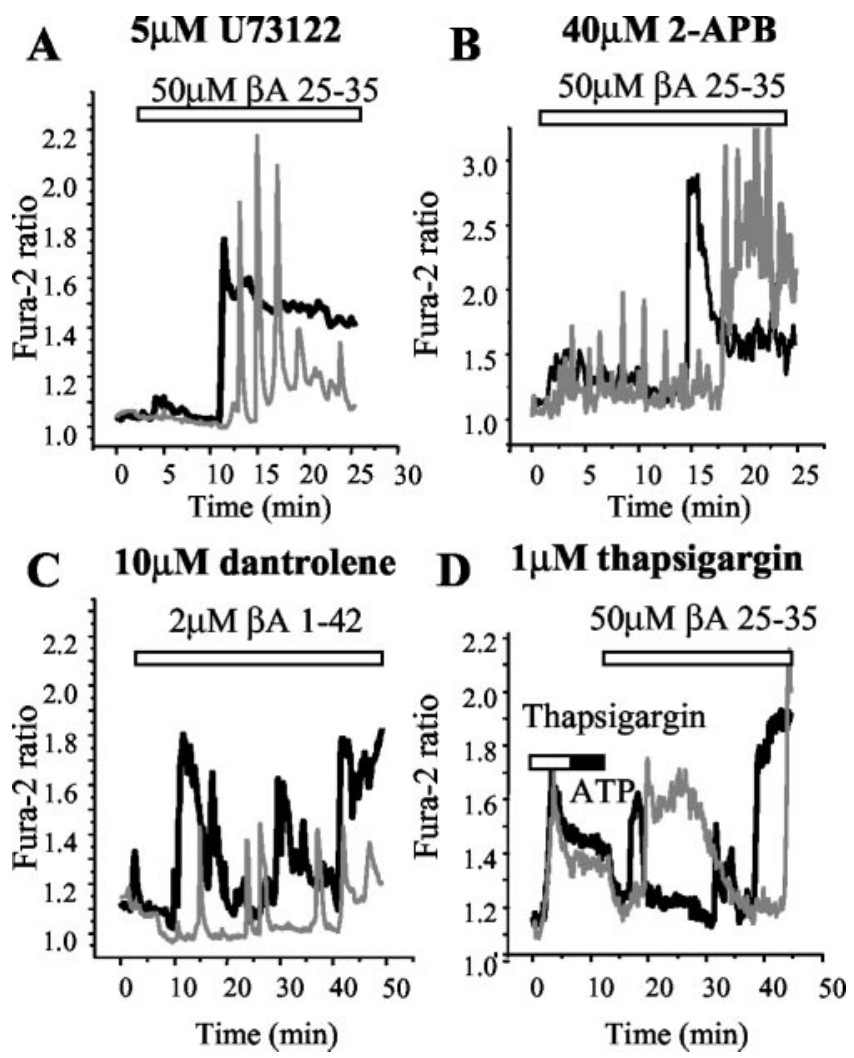

Figure 3. Intracellular $\mathrm{Ca}^{2+}$ stores do not make a significant contribution to the astrocyte $\left[\mathrm{Ca}^{2+}\right]_{c}$ response to $\beta$ A. Manipulations that either block components of the $\mathbb{P}_{3}$ and ryanodine signaling pathways or that empty ER stores do not significantly alter the astrocyte responses to $\beta A$. The application of $50 \mu \mathrm{m} \beta A 25-35$ caused $\left[\mathrm{Ca}^{2+}\right]_{\mathrm{C}}$ transients in cortical astrocytes despite the presence of $5 \mu \mathrm{m}$ U73122 (an inhibitor of PLC; $A$ ), $40 \mu \mathrm{m} 2-\mathrm{APB}(B)$ ), dantrolene (an inhibitor of ryanodine receptors; $\left(\right.$ ), and $1 \mu \mathrm{m}$ thapsigargin (an inhibitor of ER $\mathrm{Ca}^{2+}$ pumps; $D$ ), at a concentration that prevented the response to ATP $(100 \mu \mathrm{M})$.

$\beta$ A suppresses store-operated $\mathrm{Ca}^{2+}$ influx. Taken together, these data strongly suggest that ER-stored $\mathrm{Ca}^{2+}$ does not play a significant role in $\beta \mathrm{A}$-induced $\left[\mathrm{Ca}^{2+}\right]_{\mathrm{c}}$ signals.

Mitochondria may have a high $\mathrm{Ca}^{2+}$ content in astrocytes (Boitier et al., 1999), and we cannot overlook the possibility of the participation of mitochondria in $\beta \mathrm{A}$-induced $\left[\mathrm{Ca}^{2+}\right]_{c}$ signals, especially because $\mathrm{A} \beta$ causes mitochondrial damage (Casley et al., 2002b). After the depolarization of mitochondria with the uncoupler carbonyl cyanide $p$-trifluoromethoxyphenylhydrazone (FCCP; $1 \mu \mathrm{M}), \beta \mathrm{A} 25-35$ or $\beta \mathrm{A} 1-42$ still increased $\left[\mathrm{Ca}^{2+}\right]_{\mathrm{c}}$ $(n=84$ cells $)$. In the presence of FCCP, the $\left[\mathrm{Ca}^{2+}\right]_{c}$ signals were significantly increased ( $789 \pm 36$ vs $456 \pm 58 \mathrm{nM} ; p<0.005)$. This could result from a fall in ATP or through the loss of mitochondrial $\mathrm{Ca}^{2+}$ uptake. Nevertheless, FCCP did not reduce the $\beta \mathrm{A}-$ induced $\mathrm{Ca}^{2+}$ signal, showing that mitochondria cannot represent a significant source of $\mathrm{Ca}^{2+}$.

Thus, taken together, these data strongly suggest that $\beta \mathrm{A}$ causes $\left[\mathrm{Ca}^{2+}\right]_{\mathrm{c}}$ signals in astrocytes, but not in neurons, by inducing a pathway for $\mathrm{Ca}^{2+}$ influx across the plasma membrane.

\section{$\boldsymbol{\beta A}$ induces $\mathrm{Ca}^{2+}$ influx into astrocytes}

Extracellular $\mathrm{Mn}^{2+}$ enters cells via $\mathrm{Ca}^{2+}$-permeant channels and quenches the fluorescence of intracellular fura-2. This is most readily seen when the fura- 2 is excited at $\sim 360 \mathrm{~nm}$, the $\mathrm{Ca}^{2+}$ independent (isosbestic) point of the fura-2 excitation spectrum, whereas the $\mathrm{Ca}^{2+}$-dependent change of the $340 / 380 \mathrm{~nm}$ ratio is not altered. In the presence of $\beta \mathrm{A}(n=154$ cells), the signal excited at $360 \mathrm{~nm}$ was unaltered in the absence $\mathrm{Mn}^{2+}$, showing that this reliably reports a $\mathrm{Ca}^{2+}$-independent signal (Fig. 4A). However, in the presence of $40 \mu \mathrm{M} \mathrm{Mn}{ }^{2+}$, the $360 \mathrm{~nm}$ fura-2 signal showed stepwise and irreversible decreases in the signal corresponding with each transient increase in $\left[\mathrm{Ca}^{2+}\right]_{\mathrm{c}}$ (two examples are shown in Fig. 4B). This approach also allowed us to test whether $\beta$ A caused $\mathrm{Ca}^{2+}$ entry in neurons that was masked by $\mathrm{Ca}^{2+}$ buffering. However, $\beta$ A had no effect on the $360 \mathrm{~nm}$ fura- 2 signal in neurons $(n=120$ cells $)$ in the presence of $\mathrm{Mn}^{2+}$, or, as shown above, on the fura- 2 ratio, confirming the selectivity of the action of $\beta \mathrm{A}$ on astrocytes. These observations suggest that each $\left[\mathrm{Ca}^{2+}\right]_{\mathrm{c}}$ transient reflects a pulse of $\mathrm{Ca}^{2+}$ influx into the astrocytes.

Additional confocal imaging experiments showed that the $\beta A$-induced $\left[\mathrm{Ca}^{2+}\right]_{\mathrm{c}}$ signal was initiated as a rapid focal increase in $\left[\mathrm{Ca}^{2+}\right]_{\mathrm{c}}$. These responses could sometimes be seen clearly originating from a point source (Fig. $5 A, B$ ), followed by slower diffusion into the cytosol (Fig. $5 A$ ). In the examples in Figure $5 B$, the rise in $\left[\mathrm{Ca}^{2+}\right]_{\mathrm{c}}$ was restricted to a small part of the cell and failed to extend through the cytoplasm. This again is consistent with the activation of an influx pathway followed by $\mathrm{Ca}^{2+}$ buffering rather than the mobilization of ER stores, in which the amplitude and rate of rise of the signal are maintained by active propagation (Boitier et al., 1999).

\section{Routes for $\mathrm{Ca}^{2+}$ influx}

According to some authors (Ueda et al., 1997; He et al., 2002) $\beta \mathrm{A}$ may induce a $\left[\mathrm{Ca}^{2+}\right]_{\mathrm{c}}$ signal in neurons by increasing $\mathrm{Ca}^{2+}$ influx through voltage-dependent calcium channels (VDCC). Because astrocytes in our cultures do not show a $\left[\mathrm{Ca}^{2+}\right]_{\mathrm{c}}$ response to $50 \mathrm{mM}$ $\mathrm{KCl}$, it seems unlikely that they express VDCC. Nifedipine $(1 \mu \mathrm{M})$, an inhibitor of L-type VDCCs, had no effect on the shape or amplitude of the $\beta$ A-induced $\left[\mathrm{Ca}^{2+}\right]_{\mathrm{c}}$ signals (1-42 or 25-35) in either cortical or hippocampal astrocytes $(n=56$ cells), but it completely blocked the $\left[\mathrm{Ca}^{2+}\right]_{\mathrm{c}}$ response to $150 \mathrm{mM} \mathrm{KCl}$ in hippocampal neurons. The responses were also not significantly affected by inhibitors of either ionotropic or metabotropic glutamate receptors, including $20 \mu \mathrm{M}$ CNQX ( $n=98$ cells), $10 \mu \mathrm{M}(+)$-5-methyl-10,11-dihydro$5 \mathrm{H}$-dibenzo [a,d] cyclohepten-5,10-imine maleate ( $n=69$ cells) or $50 \mu \mathrm{M}(S)$-( \pm -amino-4-carboxy-methyl-phenylacetic acid $(n=$ 178 cells) (data not shown), suggesting that the responses do not reflect glutamate release into the culture.

An additional $\mathrm{Ca}^{2+}$ influx pathway expressed by glial cells and probably not in neurons is the pathway for capacitative influx (capacitative $\mathrm{Ca}^{2+}$ entry, $\mathrm{CCE}$ ). One possibility is that $\beta \mathrm{A}$ acts through altering the opening probability of this pathway. Therefore, we tested the action of lanthanum, which blocks CCE (Pizzo et al., 2001). However, $\mathrm{La}^{3+}(1 \mu \mathrm{M})$ had no effect on the responses ( $n=67$ cells) (data not shown).

It has been suggested that in some cell types, $\beta \mathrm{A}$-induced increases in the generation of ROS serve as a trigger, which then raise $\left[\mathrm{Ca}^{2+}\right]_{\mathrm{c}}$ (Varadarajan et al., 2000). The incubation of cortical and hippocampal astrocytes with the antioxidant trolox (750 $\mu \mathrm{M})$ and ascorbate ( $1 \mathrm{mM}, 45 \mathrm{~min}$ preincubation; $n=67$ cells) or the superoxide scavenger 4-hydroxy-2,2,6,6-tetramethylpiperadine-1-oxyl $(500 \mu \mathrm{M})$ plus catalase $(250 \mathrm{U} / \mathrm{ml})(n=69$ cells), which we have shown previously to be effective scavengers of ROS (Vergun et al., 2001), did not have any significant impact on the $\left[\mathrm{Ca}^{2+}\right]_{\mathrm{c}}$ response of the cells to $\beta \mathrm{A}$ (data not shown), suggesting that the production of ROS by $\beta A$ is not responsible for the $\left[\mathrm{Ca}^{2+}\right]_{\mathrm{c}}$ increases in astrocytes. 
Zinc and clioquinol abolish the $\beta A$ induced $\left[\mathrm{Ca}^{2+}\right]_{\mathrm{c}}$ response in astrocytes $\beta$ A peptides have been shown to form channels in artificial and biological membranes (Arispe et al., 1993; Lin et al., 2001; Kawahara et al., 1997). Such channels can be blocked by $\mathrm{Zn}^{2+}$ (Arispe et al., 1996). We found that the incubation of hippocampal or cortical astrocytes ( $n=253$ cells) with up to $1 \mathrm{mM} \mathrm{ZnCl}{ }_{2}$ completely prevented the effect of $\beta \mathrm{A}$ on $\left[\mathrm{Ca}^{2+}\right]_{\mathrm{c}}$ (Fig. $6 A$ ). However, the addition of $\mathrm{Zn}^{2+}$ had no effect on the $\beta$ A-induced $\left[\mathrm{Ca}^{2+}\right]_{\mathrm{c}}$ signals once they had already started (data not shown), suggesting that $\mathrm{Zn}^{2+}$ is not acting simply to block channels, but rather to prevent their formation.

$\beta$ A peptide binds to metal ions with a selectivity $\mathrm{Cu}^{2+}>\mathrm{Fe}^{3+}>\mathrm{Zn}^{2+}$ (Atwood et al., 1998), all of which promote aggregation. The addition of $\mathrm{Cu}^{2+}(1 \mu \mathrm{M}$ to $1 \mathrm{~mm}$ ) did not change the amplitude ( $456 \pm 58$ to $490 \pm 56 \mathrm{nM} ; n=81$ cells) or shape of the $\left[\mathrm{Ca}^{2+}\right]_{\mathrm{c}}$ signals in either cortical or hippocampal astrocytes (Fig. 6B), suggesting that endogenous heavy-metal ions present in the culture are sufficient to promote the aggregation of $\beta \mathrm{A}$.

$\mathrm{Cu}^{2+}$ can undergo redox cycling and generate ROS, whereas $\mathrm{Zn}^{2+}$ is not redoxactive but competes with $\mathrm{Cu}^{2+}$ for binding, and therefore inhibits the oxidant properties of metal-bound $\beta \mathrm{A}$ (Cuajungco et al., 2000). The inhibition of $\left[\mathrm{Ca}^{2+}\right]_{c}$ signals by $\mathrm{Zn}^{2+}$ does not appear to be dependent on these redox properties, because: (1) we see identical effects with both the full-length peptide and the 25-35 fragment, which does not have the metal-binding coordination site, and (2) we see no effect of antioxidants on the responses (above). Trace amounts of metals may promote aggregation in an $\alpha$-helix conformation, whereas a high concentration of $\mathrm{Zn}^{2+}$ (and to a lesser extent, $\mathrm{Cu}^{2+}$ ) promote $\beta$-sheet fibrillar aggregation, which is classically associated with $\beta$ A toxicity. The channels blocked by $\mathrm{Zn}^{2+}$ have an $\alpha$-helical structure, whereas the mechanism described here seems more likely to involve $\beta$-sheet formation because (1) $\mathrm{Zn}^{2+}$ prevents but does not reverse the response and (2) $\beta A 25-35$ cannot form $\alpha$-helical channels but can form $\beta$-sheets. Four types of conductances have been observed with $\beta A 1-42$ in lipid bilayers (Kourie et al., 2001).

Clioquinol, a chelator of $\mathrm{Cu}^{2+}, \mathrm{Zn}^{2+}$, and $\mathrm{Fe}^{2+}$, prevents aggregation and resolubilizes $\beta A$; it has also been shown to have a beneficial effect in mouse models of AD (Cherny et al., 2001; Melov, 2002). The preincubation of cells with $1-2 \mu \mathrm{M}$ clioquinol for 30 min dramatically prevented the effect of $\beta \mathrm{A}$ on $\left[\mathrm{Ca}^{2+}\right]_{\mathrm{c}}$ of cortical astrocytes $(n=207$ cells) (Fig. 6C).

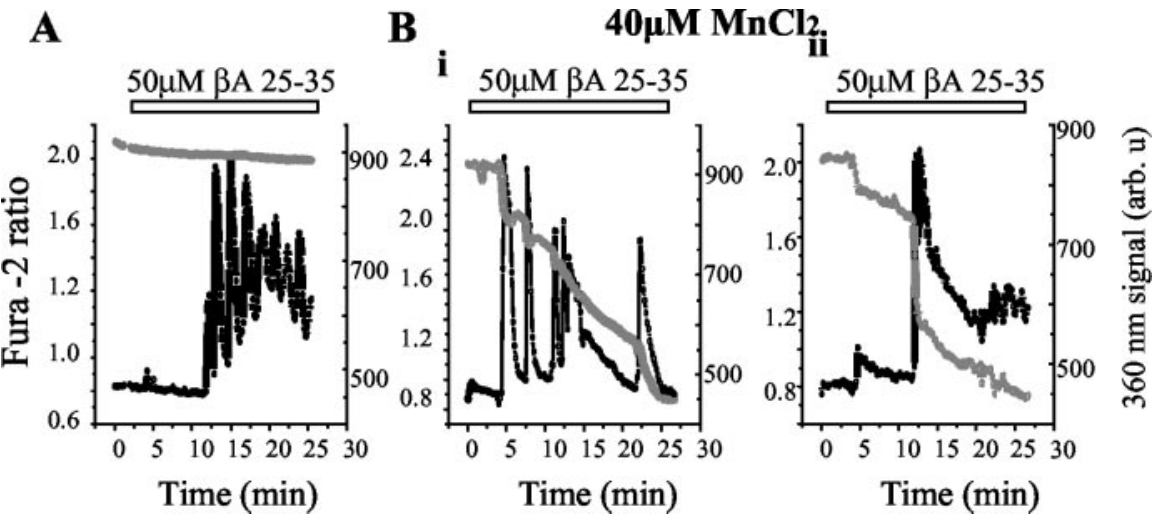

Figure 4. $\mathrm{Mn}^{2+}$ quench confirms that astrocyte $\left[\mathrm{Ca}^{2+}\right]_{\mathrm{c}}$ transients reflect transient $\mathrm{Ca}^{2+}$ influx. Fura-2-loaded hippocampal astrocytes showed typical $\left[\mathrm{Ca}^{2+}\right]_{\mathrm{C}}$ fluctuations (black line) in response to $50 \mu \mathrm{m} \beta \mathrm{A} 25-35 . \mathrm{A}$, In the absence of external $\mathrm{Mn}^{2+}$, the fura- 2 response excited at $360 \mathrm{~nm}$ (gray line) showed no change during the $\left[\mathrm{Ca}^{2+}\right]_{\mathrm{C}}$ transients, confirming that this is close to the isosbestic $\left[\mathrm{Ca}^{2+}\right]_{c}$-independent excitation wavelength for fura-2. Bi, Bii, With the addition of $40 \mu \mathrm{M} \mathrm{Mn}{ }^{2+}$ each $\left[\mathrm{Ca}^{2+}\right]_{c}$ transient was accompanied by a step quench of the $360 \mathrm{~nm}$ fura-2 signal, confirming that each transient reflects a pulsed influx of divalent cations seen in response to $\beta A 25-35$.

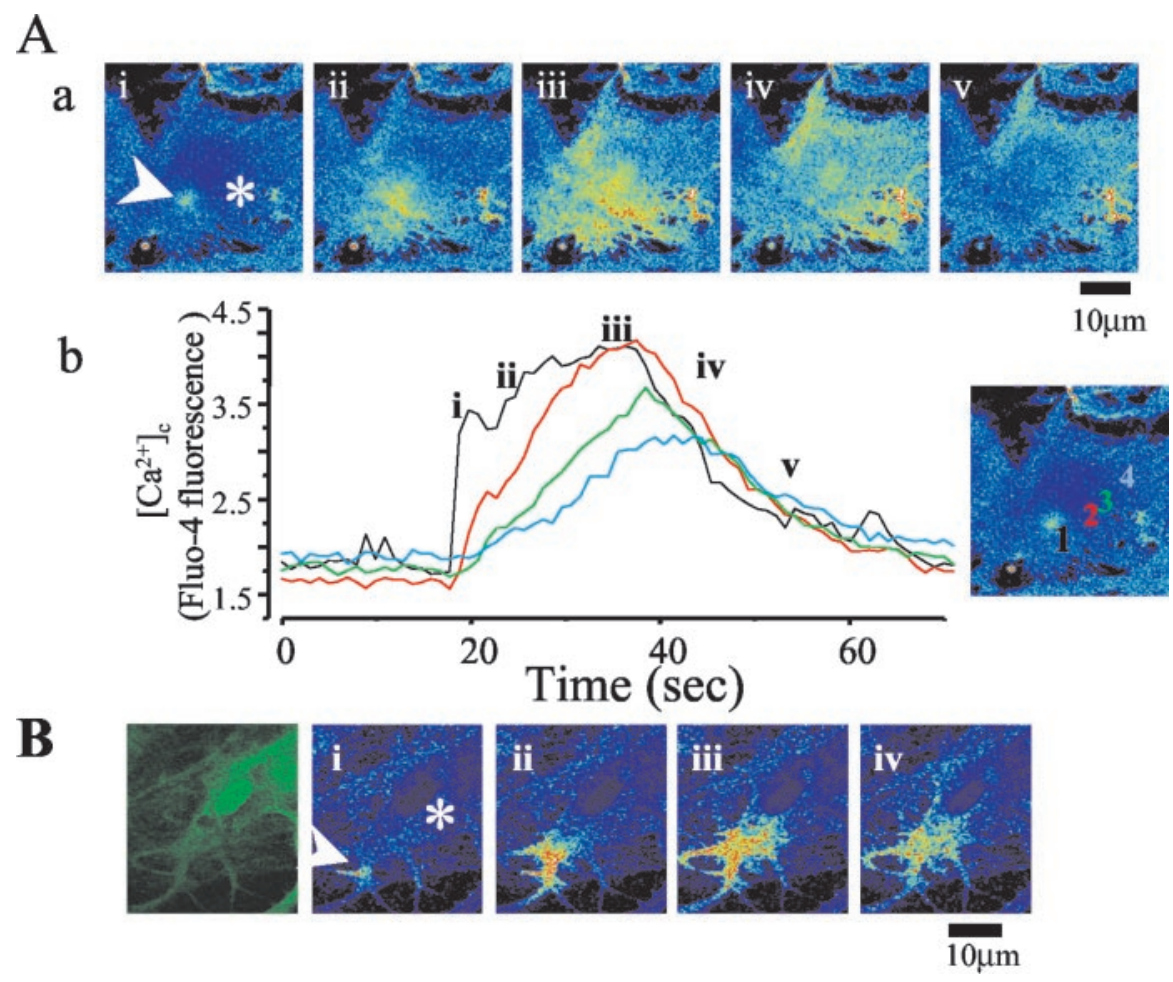

Figure 5. Confocal imaging reveals focal $\mathrm{Ca}^{2+}$ influx in response to $\beta A$. In a hippocampal coculture loaded with fluo-4, confocal imaging during the exposure to $\beta$ A shows that the change in $\left[\mathrm{Ca}^{2+}\right]_{c}$ can originate as a focal change that diffuses through the cell and may be restricted to the subplasmalemmal space. $A a$, Time series of confocal images taken during a single $\left[\mathrm{Ca}^{2+}\right]_{c}$ transient response in an astrocyte. Note that the response begins with a focal rise in $\left[\mathrm{Ca}^{2+}\right]_{\mathrm{c}}$ (arrowhead) followed by the slower spread through the cell. This is illustrated further in $A b$, which shows a plot of the signal with time at four different locations in the cell (indicated color-coded on the inset image). The rapid rate of rise at the point of influx contrasts with the much slower increase seen deep in the cytosol of the cell. $B$, Series of images taken from another astrocyte during a response to $\beta$ A25-35, again showing that the $\left[\mathrm{Ca}^{2+}\right]_{C}$ signal may be restricted to the periphery of the cell and fail to propagate through the cell. The first image of the sequence shows the raw data, whereas the subsequent images show the ratio of the image sequence with respect to the first image of the sequence.

\section{$\beta A 25-35$ and $\beta A 1-42$ deplete GSH in hippocampal neurons} and astrocytes

We then explored the consequences of $\beta \mathrm{A}$ exposure for GSH, using fluorescence imaging of the indicator MCB to identify changes in GSH in different cell types within the same culture 


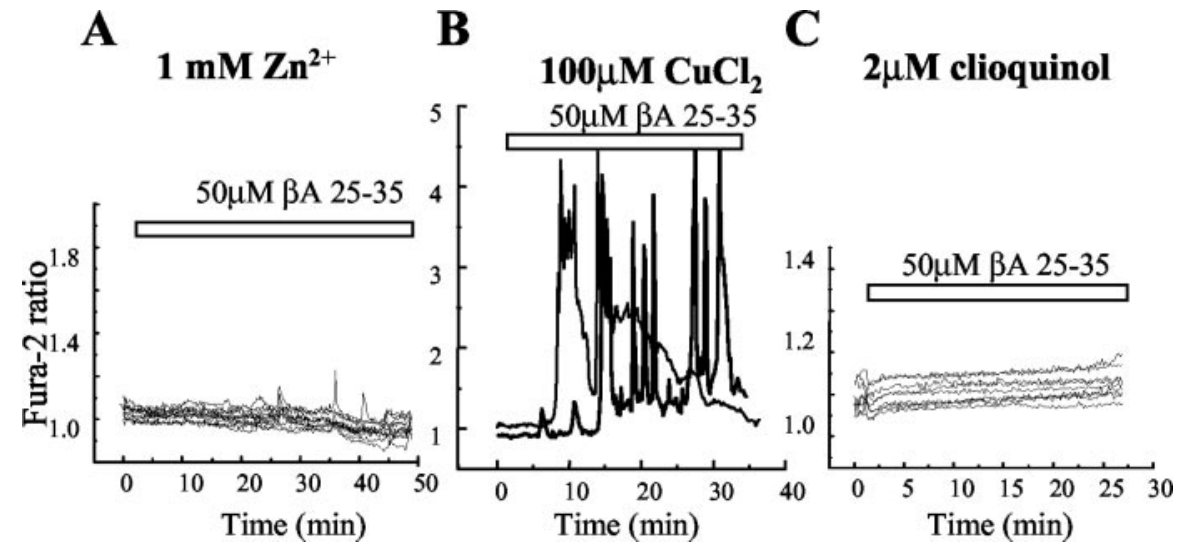

Figure 6. Responses to $\beta A$ are blocked by $\mathrm{Zn}^{2+}$ and clioquinol but not by $\mathrm{Cu}^{2+}$. $A$, Addition of zinc $\left(1 \mathrm{~mm} \mathrm{ZnCl}_{2}\right)$ suppressed the astrocyte response to $\beta \mathrm{A}$. $B$, Addition of $\mathrm{CuCl}_{2}(100 \mu \mathrm{m})$ had no apparent effect on the $\beta$ A responses, but the heavy-metal chelator clioquinol $(2 \mu \mathrm{M})(C)$ suppressed the responses completely.

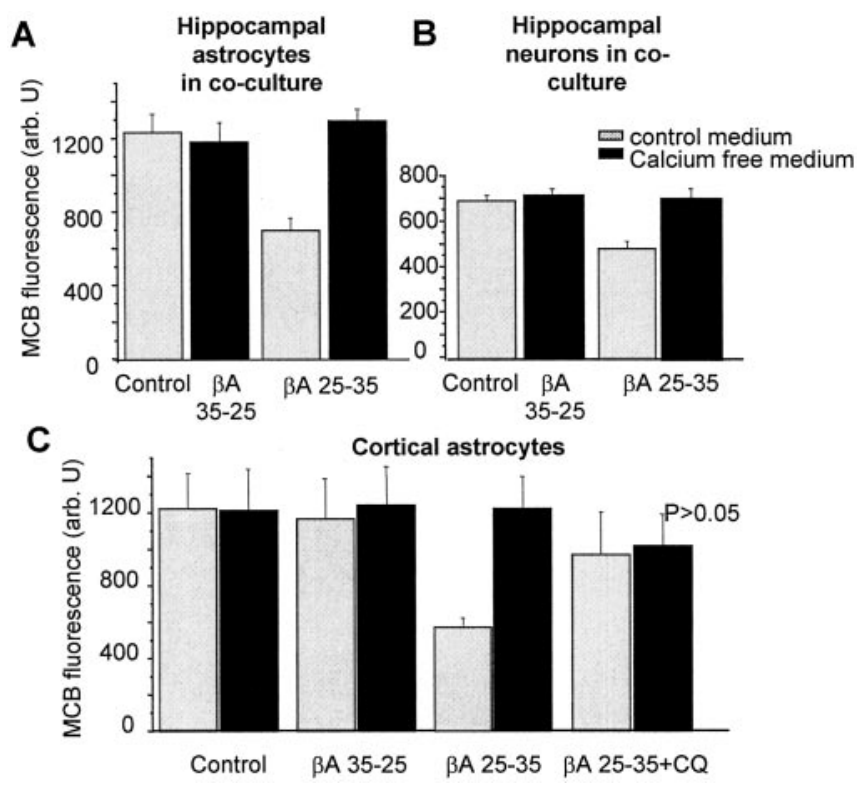

Figure 7. $\beta A$ causes $\mathrm{Ca}^{2+}$-dependent depletion of GSH in both neurons and astrocytes. $M C B$ was used to image astrocyte and neuronal GSH by digital imaging. Hippocampal cocultures (15-20 DIV) $(A, B)$ and cortical astrocyte cultures ( $C$ ) were treated for $24 \mathrm{hr}$ with $\beta$ A25-35 or $\beta A 35-25$ (50 $\mu \mathrm{m}$ for both) and clioquinol $(1 \mu \mathrm{M})$ at $37^{\circ} \mathrm{C}$ in culture medium with (gray columns) or without (black columns) calcium. Mean intensities of MCB-GSH adduct fluorescence (arb.U) are presented. $\beta$ A25-35 decreased GSH dramatically either in hippocampal astrocytes in coculture with neurons $(A)$ or in cortical astrocytes in monoculture $(C)$. The response was dependent on extracellular calcium and was also suppressed by clioquinol (C). $\beta$ A35-25 had no effect. Note that neuronal GSH was also significantly reduced $(B)$ and that the reduction was also calcium dependent, although it represents a proportionately smaller response than that of the astrocytes.

(Keelan et al., 2001). In agreement with previous reports (Casley et al., 2002a; Muller et al., 1997; White et al., 1999), we found that $\beta$ A significantly decreased GSH in cortical astrocyte monocultures (by $54.7 \pm 4.9 \%$; $n=798$ cells; $p<0.001$ ) (Fig. $7 C$ ) and in hippocampal astrocytes in coculture (by $44.32 \pm 4.9 \%$; control = $100 \%)$ (Fig. $7 A)(n=831$ cells; $p<0.005)$ after a $24 \mathrm{hr}$ incubation.

In contrast to the lack of effect of $\beta \mathrm{A}$ on neuronal $\left[\mathrm{Ca}^{2+}\right]_{\mathrm{c}}, \beta \mathrm{A}$ also significantly $(p<0.01)$ reduced GSH in hippocampal neurons (33.5 $\pm 6.3 \% ; n=345$ cells) (Fig. $7 B$ ). Because astrocytes supply neighboring neurons with GSH precursors (Sagara et al.,
1993) the GSH decline in the neurons is likely to be a secondary consequence of the decrease of astrocyte GSH.

The removal of external $\mathrm{Ca}^{2+}$ alone had no effect on GSH levels in hippocampal neurons ( $n=420$ cells) or astrocytes ( $n=905$ cells) in control experiments (Fig. 7A-C). However, the effect of $\beta A 1-42$ and $\beta A 25-35$ on GSH was abolished in the absence of $\mathrm{Ca}^{2+}$ in both hippocampal or cortical astrocytes and in hippocampal neurons (Fig. $7 A-C$ ). Thus, given the dependence of $\beta \mathrm{A}$-induced $\left[\mathrm{Ca}^{2+}\right]_{\mathrm{c}}$ fluctuations on external $\mathrm{Ca}^{2+}$, it seems likely that the GSH changes are a direct consequence of the changes in astrocyte $\left[\mathrm{Ca}^{2+}\right]_{\mathrm{c}}$.

In the presence of $1-2 \mu \mathrm{M}$ clioquinol, a concentration that abolished $\beta \mathrm{A}$-induced $\left[\mathrm{Ca}^{2+}\right]_{\mathrm{c}}$ fluctuations in astrocytes, $\beta \mathrm{A} 25-35$ (and $\beta \mathrm{A} 1-42$, data not shown) no longer caused a significant fall of GSH in cortical astrocytes ( $n=619$ cells) (Fig. 7C).

\section{Effect of $\boldsymbol{\beta A}$ on cell viability}

We then examined the effect of a $24 \mathrm{hr}$ exposure of cultures to $\beta \mathrm{A} 25-35$ on cell viability and found that, remarkably, $49.9 \pm$ $8.5 \%$ of neurons (Fig. $8 A$ ) but only $23.2 \pm 4.2 \%$ of astrocytes ( $n=9$ experiments) (Fig. $8 B$ ) died during this period in hippocampal cocultures. Preincubation with $1 \mu \mathrm{M}$ clioquinol reduced cell death of hippocampal neurons and of cocultured hippocampal astrocytes by $\sim 50 \%(21.2 \pm 6.8 \%$ dead cells, $p<0.05$, and $15.2 \pm 3.2 \%$, respectively, $n=5$ experiments) (Fig. 8 ).

The removal of $\mathrm{Ca}^{2+}$ from the medium also significantly $(p<$ 0.001 ) protected the hippocampal neurons (cell death fell from $49.9 \pm 8.5$ to $16.45 \pm 4.1 \% ; n=6$ experiments) and in cocultured hippocampal astrocytes (from $23.2 \pm 4.2$ to $17.5 \%$; $n=7$ experiments; $p>0.05)$. The presence or absence of $\mathrm{Ca}^{2+}$ in the medium did not change the percentage of dead cells in untreated cells or in cells treated with the reverse peptide 35-25 (Fig. 8A,B).

\section{Discussion}

We have found that $\beta \mathrm{A}$ induces calcium signals selectively in astrocytes causing sporadic fluctuations of $\left[\mathrm{Ca}^{2+}\right]_{\mathcal{c}}$, while having no apparent effect at all on $\left[\mathrm{Ca}^{2+}\right]_{c}$ in nearby neurons. The $\left[\mathrm{Ca}^{2+}\right]_{\mathrm{c}}$ signals are dependent on calcium influx from the extracellular space and are inhibited by $\mathrm{Zn}^{2+}$ or by the heavy-metal chelator clioquinol. Our data are most readily consistent with a model in which $\beta \mathrm{A}$ inserts into the plasma membrane, in which it either forms channels or influences the properties of an existent $\mathrm{Ca}^{2+}$-permeant channel. Several features of the responses are remarkable in this respect: most notably, the selectivity of the response for the astrocytes and the oscillatory, transient nature of the $\left[\mathrm{Ca}^{2+}\right]_{\mathrm{c}}$ signals. One might anticipate that insertion of $\mathrm{Ca}^{2+}$ permeant channels into a cell membrane would generate a monotonic increase in $\left[\mathrm{Ca}^{2+}\right]_{c}$, and the appearance of the transient fluctuations were surprising. However, the $\mathrm{Mn}^{2+}$ quench and confocal imaging data strongly argue that the transients do indeed result from transient episodic $\mathrm{Ca}^{2+}$ influx and so presumably reflect either the sporadic openings of a channel with a low opening probability or the transient formation of channels that then dissociate.

The other major original findings reported here are that $\beta \mathrm{A}$ affects $\left[\mathrm{Ca}^{2+}\right]_{\mathrm{c}}$ signals in astrocytes but not in neurons and that 


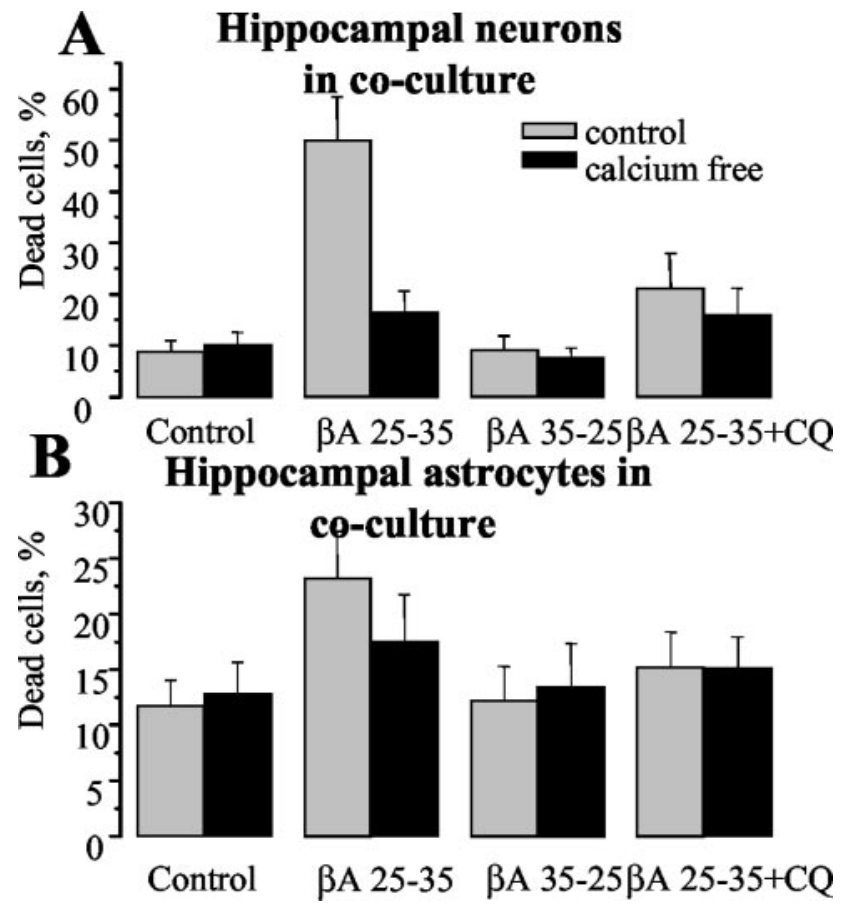

Figure 8. $\quad \beta A$ causes $\mathrm{Ca}^{2+}$-dependent cell death in neurons and not in astrocytes. Effect of $\beta A$ on viability of neurons and astrocytes. PI fluorescence was used to detect dead cells $24 \mathrm{hr}$ after the addition of $50 \mu \mathrm{m} \beta \mathrm{A}$ and $1 \mu \mathrm{m}$ clioquinol in the presence or absence of $\mathrm{Ca}^{2+}$. Dead cells were counted with respect to the total number of cells present, identified by staining nuclei with Hoechst 33342. $\beta$ A caused a dramatic increase in cell death in neurons and only a modest increase in astrocyte cell death in hippocampal cocultures. Cell death was calcium dependent and cells were dramatically protected by $1 \mu \mathrm{m}$ clioquinol.

the ensuing neurotoxicity appears to be secondary to impaired astrocytic function in the support of neuronal viability, although we cannot exclude a direct toxic effect of the $\beta$ A on neurons. In most published studies of $\beta$ A neurotoxicity, either neuronal cell lines were used (Blanchard et al., 1997), or, in studies of neurons in primary culture, the presence and contribution of glial cells was not excluded (Mattson et al., 1992; Pike et al., 1993). The selectivity of the effects on $\left[\mathrm{Ca}^{2+}\right]_{\mathrm{c}}$ for astrocytes is remarkable and may reflect some difference in the plasma membrane lipid composition of the two cell types, because even small differences in the lipid environment affect $\beta \mathrm{A}$ binding to membranes and pore formation (Curtain et al., 2003). The stability of $\beta$ A aggregates in membranes is very delicately balanced (McLaurin and Chakrabarty, 1996). For example, increased membrane cholesterol, such as is found in $\mathrm{AD}$ brain and aging, favors a $\beta$-sheet over an $\alpha$-helix conformation of $\beta$ A (Curtain et al., 2003). To our knowledge, very little information is available on the membrane composition in different brain-cell types. Alternatively, the selectivity may reflect the selective effects of $\beta A$ on an existing channel, which is expressed in astrocytes but not in neurons, although our pharmacological search has failed to reveal such a process.

In conclusion, our experimental conditions have allowed us to uncover a novel toxic mechanism of $\beta$ A, probably overlapping in vivo with other known effects. This involves $\beta$-aggregation of $\beta \mathrm{A}$ and the selective insertion into the astrocyte plasma membrane, initiating sporadic $\left[\mathrm{Ca}^{2+}\right]_{\mathrm{c}}$ signals, which can persist over long periods. These signals, although not causing astrocyte cell death, nevertheless promote GSH depletion in both cell populations; they ultimately impair neuronal viability because GSH depletion leaves the neurons vulnerable to damage by oxidative stress. Thus, the resulting neurotoxicity reflects the central role of astro- cytes in supporting neuronal function by supplying GSH precursors and other metabolic intermediates and by removing excess glutamate from the extracellular medium.

\section{References}

Arispe N, Rojas E, Pollard HB (1993) Alzheimer disease amyloid $\beta$ protein forms calcium channels in bilayer membranes: blockade by tromethamine and aluminum. Proc Natl Acad Sci USA 90:567-571.

Arispe N, Pollard HB, Rojas E (1996) $\mathrm{Zn}^{2+}$ interaction with Alzheimer amyloid $\beta$ protein calcium channels. Proc Natl Acad Sci USA 93:1710-1715.

Atwood CS, Moir RD, Huang X, Scarpa RC, Bacarra NM, Romano DM, Hartshorn MA, Tanzi RE, Bush AI (1998) Dramatic aggregation of Alzheimer $\mathrm{A} \beta$ by $\mathrm{Cu}(\mathrm{II})$ is induced by conditions representing physiological acidosis. J Biol Chem 273:12817-12826.

Behl C, Davis JB, Lesley R, Schubert D (1994) Hydrogen peroxide mediates amyloid $\beta$ protein toxicity. Cell 77:817-822.

Blanchard BJ, Konopka G, Russell M, Ingram VM (1997) Mechanism and prevention of neurotoxicity caused by $\beta$-amyloid peptides: relation to Alzheimer's disease. Brain Res 776:40-50.

Boitier E, Rea R, Duchen MR (1999) Mitochondria exert a negative feedback on the propagation of intracellular $\mathrm{Ca}^{2+}$ waves in rat cortical astrocytes. J Cell Biol 145:795-808.

Casley C, Land J, Sharpe M, Clark J, Duchen M, Canevari L (2002a) $\beta$-Amyloid fragment 25-35 causes mitochondrial dysfunction in primary cortical neurons. Neurobiol Dis 10:258-267.

Casley CS, Canevari L, Land JM, Clark JB, Sharpe MA (2002b) $\beta$-Amyloid inhibits integrated mitochondrial respiration and key enzyme activities. J Neurochem 80:91-100.

Charles AC, Merrill JE, Dirksen ER, Sanderson MJ (1991) Intercellular signaling in glial cells: calcium waves and oscillations in response to mechanical stimulation and glutamate. Neuron 6:983-992.

Cherny RA, Atwood CS, Xilinas ME, Gray DN, Jones WD, McLean CA, Barnham KJ, Volitakis I, Fraser FW, Kim Y, Huang X, Goldstein LE, Moir RD, Lim JT, Beyreuther K, Zheng H, Tanzi RE, Masters CL, Bush AI (2001) Treatment with a copper-zinc chelator markedly and rapidly inhibits beta-amyloid accumulation in Alzheimer's disease transgenic mice. Neuron 30:665-676.

Cuajungco MP, Goldstein LE, Nunomura A, Smith MA, Lim JT, Atwood CS, Huang X, Farrag YW, Perry G, Bush AI (2000) Evidence that the $\beta$-amyloid plaques of Alzheimer's disease represent the redox-silencing and entombment of a $\beta$ by zinc. J Biol Chem 275:19439-19442.

Curtain CC, Ali FE, Smith DG, Bush AI, Masters CL, Barnham KJ (2003) Metal ions, $\mathrm{pH}$ and cholesterol regulate the interactions of Alzheimer's disease amyloid- $\beta$ peptide with membrane lipid. J Biol Chem 278:2977-2982.

Dringen R (2000) Metabolism and function of glutathione in brain. Prog Neurobiol 62:649-671.

Grynkiewicz G, Poenie M, Tsien RY (1985) A new generation of $\mathrm{Ca}^{2+}$ indicators with greatly improved fluorescence properties. J Biol Chem 260:3440-3450.

Harkany T, Abraham I, Timmerman W, Laskay G, Toth B, Sasvari M, Konya C, Sebens JB, Korf J, Nyakas C, Zarandi M, Soos K, Penke B, Luiten PG (2000) beta-amyloid neurotoxicity is mediated by a glutamate-triggered excitotoxic cascade in rat nucleus basalis. Eur J Neurosci 12:2735-2745.

Haydon PG (2001) Glia: listening and talking to the synapse. Nat Rev Neurosci 2:185-193.

He LM, Chen LY, Lou XL, Qu AL, Zhou Z, Xu T (2002) Evaluation of $\beta$-amyloid peptide $25-35$ on calcium homeostasis in cultured rat dorsal root ganglion neurons. Brain Res 939:65-75.

Kawahara M, Arispe N, Kuroda Y, Rojas E (1997) Alzheimer's disease amyloid $\beta$-protein forms $\mathrm{Zn}^{2+}$-sensitive, cation-selective channels across excised membrane patches from hypothalamic neurons. Biophys J 73:67-75

Keelan J, Allen NJ, Antcliffe D, Pal S, Duchen MR (2001) Quantitative imaging of glutathione in hippocampal neurons and glia in culture using monochlorobimane. J Neurosci Res 66:873-884.

Kourie JI, Henry CL, Farrelly P (2001) Diversity of amyloid $\beta$ protein fragment [1-40]-formed channels. Cell Mol Neurobiol 21:255-284.

Lin H, Bhatia R, Lal R (2001) Amyloid $\beta$ protein forms ion channels: implications for Alzheimer's disease pathophysiology. FASEB J 15:2433-2444. 
Markesbery WR (1997) Oxidative stress hypothesis in Alzheimer's disease. Free Rad Biol Med 23:134-147.

Mattson MP, Chan SL (2001) Dysregulation of cellular calcium homeostasis in Alzheimer's disease: bad genes and bad habits. J Mol Neurosci 17:205-224.

Mattson MP, Cheng B, Davis D, Bryant K, Lieberburg I, Rydel RE (1992) $\beta$-Amyloid peptides destabilize calcium homeostasis and render human cortical neurons vulnerable to excitotoxicity. J Neurosci 12:376-389.

Matyash M, Matyash V, Nolte C, Sorrentino V, Kettermann H (2002) Requirement of functional ryanodine receptor type 3 for astrocyte migration. FASEB J 16:84-86.

McLaurin J, Chakrabartty A (1996) Membrane disruption by Alzheimer $\beta$-amyloid peptides mediated through specific binding to either phospholipids or gangliosides: implications for neurotoxicity. J Biol Chem 271:26482-26489.

Meske V, Hamker U, Albert F, Ohm TG (1998) The effects of $\beta / A 4$-amyloid and its fragments on calcium homeostasis, glial fibrillary acidic protein and $\mathrm{S} 100 \beta$ staining, morphology and survival of cultured hippocampal astrocytes. Neuroscience 85:1151-1160.

Melov S (2002) “. . . and C is for Clioquinol": the A $\beta C$ s of Alzheimer's disease. Trends Neurosci 25:121-123.

Muller WE, Romero FJ, Perovic S, Pergande G, Pialoglou P (1997) Protection of flupirtine on $\beta$-amyloid-induced apoptosis in neuronal cells in vitro: prevention of amyloid-induced glutathione depletion. J Neurochem 68:2371-2377.

Peuchen S, Clark JB, Duchen MR (1996) Mechanisms of intracellular calcium regulation in adult astrocytes. Neuroscience 71:871-883.

Pike CJ, Burdick D, Walencewicz AJ, Glabe CG, Cotman CW (1993) Neurodegeneration induced by $\beta$-A peptides in vitro: the role of peptide assembly state. J Neurosci 13:1676-1687.

Pizzo P, Burgo A, Pozzan T, Fasolato C (2001) Role of capacitative calcium entry on glutamate-induced calcium influx in type-I rat cortical astrocytes. J Neurochem 79:98-109.

Rovira C, Arbez N, Mariani J (2002) $\mathrm{A} \beta$ (25-35) and $\mathrm{A} \beta$ (1-40) act on different calcium channels in CA1 hippocampal neurons. Biochem Biophys Res Commun 296:1317-1321.

Sagara J, Miura K, Bannai S (1993) Maintenance of neuronal glutathione by glial cells. J Neurochem 61:1672-1676.

Schubert P, Ogata T, Marchini C, Ferroni S (2001) Glia-related pathomechanisms in Alzheimer's disease: a therapeutic target? Mech Ageing Dev 123:47-57.

Small DH, McLean C (1999) Alzheimer's disease and the amyloid- $\beta$ protein: what is the role of amyloid? J Neurochem 73:443-449.

Stix B, Reiser G (1998) $\beta$-Amyloid peptide 25-35 regulates basal and hormone-stimulated $\mathrm{Ca}^{2+}$ levels in cultured rat astrocytes. Neurosci Lett 243:121-124.

Takahashi M, Billups B, Rossi D, Sarantis M, Hamann M, Attwell D (1997) The role of glutamate transporters in glutamate homeostasis in the brain. J Exp Biol 200:401-409.

Ueda K, Shinohara S, Yagami T, Asakura K, Kawasaki K (1997) Amyloid $\beta$ protein potentiates $\mathrm{Ca}^{2+}$ influx through L-type voltage-sensitive $\mathrm{Ca}^{2+}$ channels: a possible involvement of free radicals. J Neurochem 68:265-271.

Varadarajan S, Yatin S, Aksenova M, Butterfield DA (2000) Alzheimer's amyloid $\beta$-peptide-associated free radical oxidative stress and neurotoxicity. J Struct Biol 130:184-208.

Vergun O, Sobolevsky AI, Yelshansky MV, Keelan J, Khodorov BI, Duchen MR (2001) Exploration of the role of reactive oxygen species in glutamate neurotoxicity in rat hippocampal neurones in culture. J Physiol (Lond) 531:147-163.

White AR, Bush AI, Beyreuther K, Masters CL, Cappai R (1999) Exacerbation of copper toxicity in primary neuronal cultures depleted of cellular glutathione. J Neurochem 72:2092-2098. 